\title{
Pengembangan Game Edukasi Bahasa Isyarat Tentang Pengelolaan Sampah Berbasis Android
}

\author{
Imam Fauzy Muldani Rachmat ${ }^{1}$, Gazali ${ }^{2}$ \\ ${ }^{1,2}$ Jurusan Sistem Informasi, STMIK Insan Pembangunan \\ ${ }^{1,2}$ Jl. Raya Serang No.Km. 10, Kadu Jaya, Kec. Curug, Tangerang \\ e-mail: ${ }^{1}$ imamfauzi43@ipem.ac.id, ${ }^{2}$ gazali37@ipem.ac.id
}

\begin{abstract}
Abstrak
Membuang sampah sembarangan akan berdampak negatif bagi lingkungan seperti pencemaran lingkungan, mengakibatkan banjir serta dampak bagi kesehatan, oleh karena itu kesadaran membuang sampah beserta memilah pada tempatnya merupakan sikap yang perlu ditanamkan pada setiap masing individu. Berdasarkan survey siswa/siswi tunarungu SLBN Banjar dapat disimpulkan masih belum paham tentang pengelolaan sampah dan kurang peduli dalam membuang sampah pada tempatnya. Penyelesaian terhadap permasalahan tersebut yaitu dengan menerapkan pembelajaran pengelolaan sampah melalui pengembangan game edukasi bahasa isyarat menggunakan pendekatan siklus pengembangan game. Hasil dari pengembangan ini adalah game dengan fitur level menggunakan bahasa isyarat yaitu Levell mengenal jenis sampah, Level2 Memilah sampah, dan Level3 recycle sampah, sedangkan fitur tambahannya Splashscreen, menu utama, pengenalan sampah, belajar SIBI, Info games. Hasil pengujian Blackbox mendapatkan hasil valid dan pengujian usability Nielsen berdasarkan aspek Learnability 80\%(Baik), Efficiency 73\%(Baik), Memorability 73.33\%(Baik), Error 79\%(Baik), Satisfaction $82.67 \%$ (Sangat Baik) sehingga rata-rata nilai pengujian usability Nielsen sebesar $77 \%$ dikategorikan baik.
\end{abstract}

Kata kunci: Game Edukasi, Bahasa Isyarat, Sampah Organik,Sampah Anorganik

\begin{abstract}
Careless disposal of garbage has negative effects on the environment., such as environmental pollution, resulting in flooding and impacts on health. Therefore, the awareness of disposing of waste and sorting it in its place is an attitude that must be applied to every individual. The problem is that the deaf students of SLBN Banjar can be concluded that they still do not understand waste management and are less concerned about disposing of waste in its place. The solution to this problem is to apply waste management learning through sign language educational games using a game development cycle approach. The result of this development is a game with level features using sign language, namely Levell recognizes the type of waste, Level2 sorts waste, and Level3 recycles waste, while the additional features are Splashscreen, main menu, the introduction of waste, learning SIBI, Info games. The results of the Blackbox test get valid results and Nielsen's usability test based on aspects of Learnability 80\% (Good), Efficiency 73\% (Good), Memorability 73.33\% (Good), Error 79\% (Good), Satisfaction $82.67 \%$ (Very Good) so that the average Nielsen's average usability test score of $77 \%$ is categorized as good.
\end{abstract}

Keywords: Educational Games, Sign Language, Organic Garbage, Inorganic Garbage

\section{Pendahuluan}

Permasalahan sampah akan berdampak buruk bagi lingkungan seperti pencemaran lingkungan, mengakibatkan banjir serta dampak bagi kesehatan apabila kepedulian lingkungan tidak diterapkan. Berdasarkan Indeks Perilaku Ketidakpedulian Lingkungan Hidup(IPKLH) sebesar $81,4 \%$ rumah tangga yang menimbun dan menghasilkan sampah, dan sisanya 18,6\%, yang peduli dengan sampah [1]. Hal ini menunjukan masih banyak yang kurang peduli dengan lingkungannya, sehingga mendorong pemerintah mengkampanyekan pilah sampah melalui 
gerakan nasional pilah sampah yang dimulai dari lingkungan rumah masig-masing. Sikap peduli lingkungan tentang pengelolaan sampah perlu ditanamkan pada lingkungan sekolah melalui sikap peduli lingkungan, hal ini akan membentuk karakter manusia yang berkontribusi untuk kepentingan masyarakat dari perilaku hal yang sangat kecil seperti membuang dan memilah sampah pada tempatnya. Selain itu, Hasil belajar yang berkaitan dengan kepedulian terhadap lingkungan dapat mengubah sikap siswa/siswi menjadi lebih positif terhadap lingkungan [2]. Penerapan pembelajaran sikap peduli lingkungan terkait pengelolaan sampah pada siswa/siswi tunarungu di SLB dapat diimplementasikan pada materi pembelajaran bahasa isyarat dengan tema sikap peduli lingkungan tentang pengelolaan sampah. Sehingga dari pembelajaran bahasa isyarat akan diperoleh pengetahuan pengelolaan sampah seperti pengenalan jenis sampah, memilah sampah pada tempatnya dan daur ulang sampah. Berdasarkan hasil kuesioner mengenai pemahaman pengelolaan sampah pada siswa/wi tunarungu di SLBN Kota Banjar, dapat disimpulkan masih banyak yang kurang paham, dan masih ada yang kurang peduli dalam membuang sampah pada tempatnya. Penyelesaian dari masalah tersebut adalah mengembangkan game edukasi pengelolaan sampah yang dapat membantu siswa tunarungu yang menyenangkan tentang pengelolaan sampah melalui pengetahuan SIBI(Sistem Isyarat Bahasa Indonesia) yang ditetapkan oleh pemerintah[3]. Manfaat game edukasi dapat meningkatkan memori melalui animasi yang interaktif, dan memungkinkan pemain untuk menyimpan konten lebih lama dibandingkan dengan metode pembelajaran konvensional [4].

Penelitian relevan tentang pembuatan game edukasi tentang sampah sebelumnya yaitu Helfi dan Anggi yang berjudul "Edukasi Game Jaga Sungai Kapuas Berbasis Android Menggunakan Construct 2" menghasilkan sebuah edugame dengan gameplay mengumpulkan sampah di sungai kapuas, game yang dibangun menggunakan sistem Computer Assisted Instruction (CAI) dan metode pembelajaran menggunakan latihan dengan menggerakan perahu untuk mengumpulkan sampah, aspek yang diuji Functionality, Efficiency, Usability, Portability [5]. Selain itu penelitian sebelumnya oleh Sussi dkk yang berjudul " Pembuatan Game Online BoMCleaN sebagai Media Pembelajaran Kebersihan Lingkungan" dengan gameplay yang disediakan mengambil sampah organik dan anorganik yang terjatuh, aspek yang diuji desain game, bug, alur permainan, tingkat tantangan, sedangkan untuk target audience adalah ibu rumah tangga, wanita profesi dan mahasiswa [6]. Kemudian penelitian Muhamad dan Suwarni yang berjudul "Perancangan dan Implementasi Game Edukasi Pengolahan Sampah Organik dan Anorganik Berbasis Android Pada Kelas VII SMP Fajar Sentosa" menghasilkan game pembelajaran pengelolaan sampah untuk pembelajaran bagi siswa SMP Fajar Sentosa Kelas VII dengan metode SDLC (System Development Life Cycle) pembelajarannya menggunakan latihan memindahkan sampah ke mesin kemudian dipindahkan ke truk pengangkut sampah, target audience adalah Siswa SMP Fajar Sentosa kelas VI, pengujian menggunakan skala guttman [7]. Berdasarkan penelitian terdahulu maka pendekatan pengembangan game yang digunakan adalah GDLC(Game Development Life Cycle). Unsur kebaruan dari penelitian ini adalah penerapan pemanfaatan pembelajaran simulasi recycle sampah organik dan anorganik pada pembelajaran bahasa isyarat jenis SIBI, penerapan usability testing menggunakan model nielsen yang terdiri dari aspek learnability, efficiency, memorability, error, satisfaction dengan penilaian skala likert yang belum ada pada penelitian terdahulunya.

\section{Metode Penelitian}

Objek penelitian berdasarkan studi kasus SLBN Kota banjar melalui tahapan pengembangan game dimulai dari initiation, preproduction, production, testing, beta dan release yang ditunjukan pada gambar 1[8]. Pada awalnya pendekatan yang biasa digunakan untuk membangun edugame adalah SDLC(System Development Life Cycle) tetapi tidak murni dan tidak sesuai dengan kreatifitas seni dan imajinasi dalam mengembangkan sebuah game,oleh karena itu metode yang sesuai adalah (GDLC) Game Devlopment Life Cycle [9].

\section{Tahapan Initiation}

Tahap initiation menentukan ide konsep game yang dibuat gameplay dan kebutuhan pengguna harus sudah dipersiapkan karena akan digunakan untuk menentukan storyboard game ke 
tahapan berikutnya. Untuk menentukan ide konsep game pada pembuatan game edukasi bahasa isyarat tentang pengelolaan sampah dapat dilakukan melalui studi literatur. Karena penerapannya adalah bahasa isyarat maka target audience siswa/siswi tunarungu di SLBN Banjar.

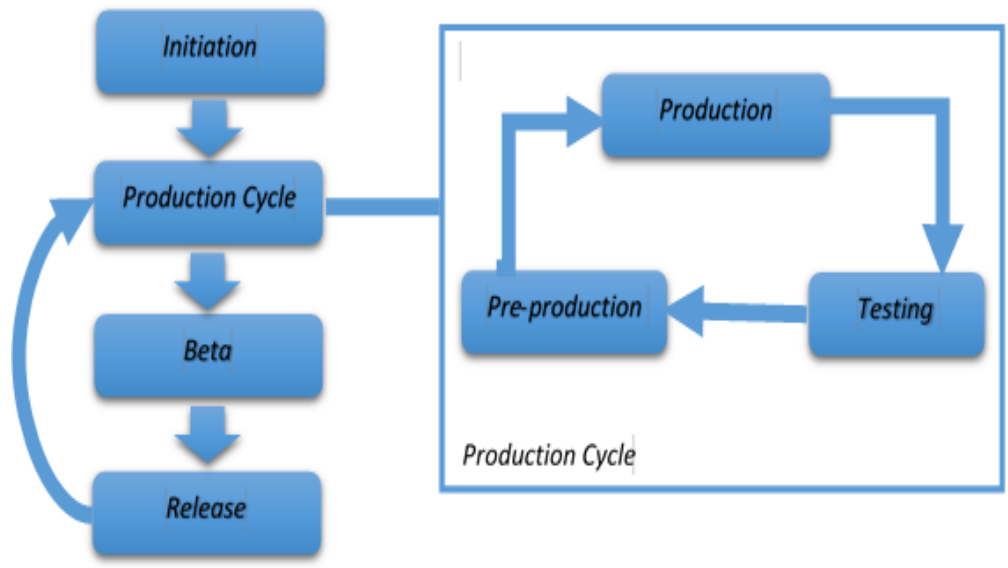

\section{Tahapan Production Cycle}

Gambar 1.Metode Game Development Life Cycle

\section{a. Pre-production}

Fase pra-produksi merupakan awal dari awal dari production cycle, penyusunan alur skenario game. Untuk memperjelas fungsionalitas game maka dapat dilakukan perancangan UML (Unified Modelling Language). Hasil akhir dari tahapan ini didokumentasikan dalam bentuk GDD (Game Design Document), sebagai dokumen acuan untuk tahap berikutnya. Dokumen perancangan game $(G D D)$ meliputi Ddeskripsi permainan(game overview), ragam permainan(genre), pengguna(target audience), tampilan(look and fee)l,fitur(feature set), Mission/challenge/ level (hadiah dan alur permainan)reward dan play flow[10].

\section{b. Production}

Pada tahapan ini, merupakan implementasi dari tahap pra-produksi dan kompilasi asset menjadi game. Aktifitas ini meliputi implementasi hasil storyboard dan arstitektur game (UML) menjadi sebuah game. Tool untuk desain user interface dan aset material menggunakan software Inskscape. Setelah aset material game selesai dibuat selanjutnya diintegrasikan dan diberikan suatu event/behaviour pada suatu objek menggunakan software game engine Construct 2.

\section{c.Testing}

Setelah game edukasi selesai dibangun selanjutnya dilakukan pengujian menggunakan metode blackbox testing yaitu pengujian berdasarkan spesifikasi fungsional aplikasi yang bertujuan mengetahui fungsi dari fitur game.[11]. Tahapan ini sangat menentukan apakah pengembangan game edukasi tersebut dapat dilanjutkan ke tahapan berikutnya yaitu pengujian beta atau dilakukan perbaikan dulu apabila masih terdapat bug atau ada fungsi yang belum sesuai yaitu kembali ke tahapan production.

\section{Tahapan Beta}

Kegiatan pada tahapan ini dilakukan apabila sudah tidak ada perbaikan pada tahapan blackbox testing pada production cycle. Game edukasi yang sudah diuji oleh pihak internal selanjutkan dilakukan feedback dari pengguna. Untuk mendapatkan feedback maka digunakan metode pengujian usability testing model Nielsen yang dilakukan oleh siswa/siswi tunarungu untuk menentukan apakah game yang diuji dari segi penggunaan dapat diterima baik atau tidak. Pengujian ini meliputi learnability, efficiency, memorability, errors, dan satisfaction[12]. Penilaian tes didasarkan pada metode skala Likert dengan skala lima poin, mulai dari nilainya terbesar sampai terkecil yaitu Excelent, Good, Average, Poor,Very Poor[13]. Proses perhitungan persentase pada skala likert dapat dilakukan dengan cara membagi total nilai maksimum skala Likert dengan 100\% kemudian dikalikan dengan 100\% sehingga nilai intervalnya adalah $20 \%[14]$. 


\section{Hasil dan Pembahasan}

\subsection{Initiation}

Peneliti melakukan wawancara narasumber yaitu guru SLB yang mengajar bahasa isyarat dan menari studi literatur terkait pengetahuan pengelolaan sampah. Ide dan konsep game dapat dituangkan melalui alur skenario game yang disebut storyline. Komponen yang terdapat pada storyline game edukasi bahasa isyarat tentang pengelolaan sampah terdiri dari nomor scene, fitur game, deskripsi dan asset material. Berikut adalah cuplikan beberapa scene storyline game dapat ditunjukan pada tabel 1 .

Tabel 1. Cuplikan Storyline Game Edukasi

\begin{tabular}{|c|c|c|c|}
\hline $\begin{array}{l}\text { Sce } \\
\text { ne }\end{array}$ & Fitur & Deskripsi & Komponen Aset \\
\hline 1 & $\begin{array}{l}\text { SploashS } \\
\text { creen }\end{array}$ & $\begin{array}{l}\text { Pertama Pemain } \text { Tabel } \\
\text { 1membuka aplikasi game } \\
\text { maka akan muncul } \\
\text { tampilan } \\
\text { SplashScreen }\end{array}$ & $\begin{array}{l}\text { Judul game Progressbar } \\
\text { Background Logo } \\
\text { STMIK Insan } \\
\text { Pembangunan } \\
\text { Logo Ristek BRIN }\end{array}$ \\
\hline 2 & $\begin{array}{l}\text { Menu } \\
\text { Utama }\end{array}$ & $\begin{array}{l}\text { Pemain dapat memilih sub } \\
\text { menu yaitu Bermain } \\
\text { (permainan } \\
\text { dimulai),Belajar (Berisi } \\
\text { sub menu yaitu belajar } \\
\text { SIBI, Pengenalan Sampah, } \\
\text {,Info (Menjelaskan } \\
\text { Informasi Terkait Peneliti). }\end{array}$ & $\begin{array}{l}\text { Judul game Button Asset } \\
\text { Background Menu Logo } \\
\text { STMIK IP Logo Ristek } \\
\text { BRIN }\end{array}$ \\
\hline
\end{tabular}

\subsection{Pre-production}

Selanjutnya setelah storyline dibangun, maka dibuat storyboard untuk menggambarkan skenario game. Berikut adalah storyboard game berdasarkan hasil dari storyline pada game edukasi dapat ditunjukan pada gambar 2.

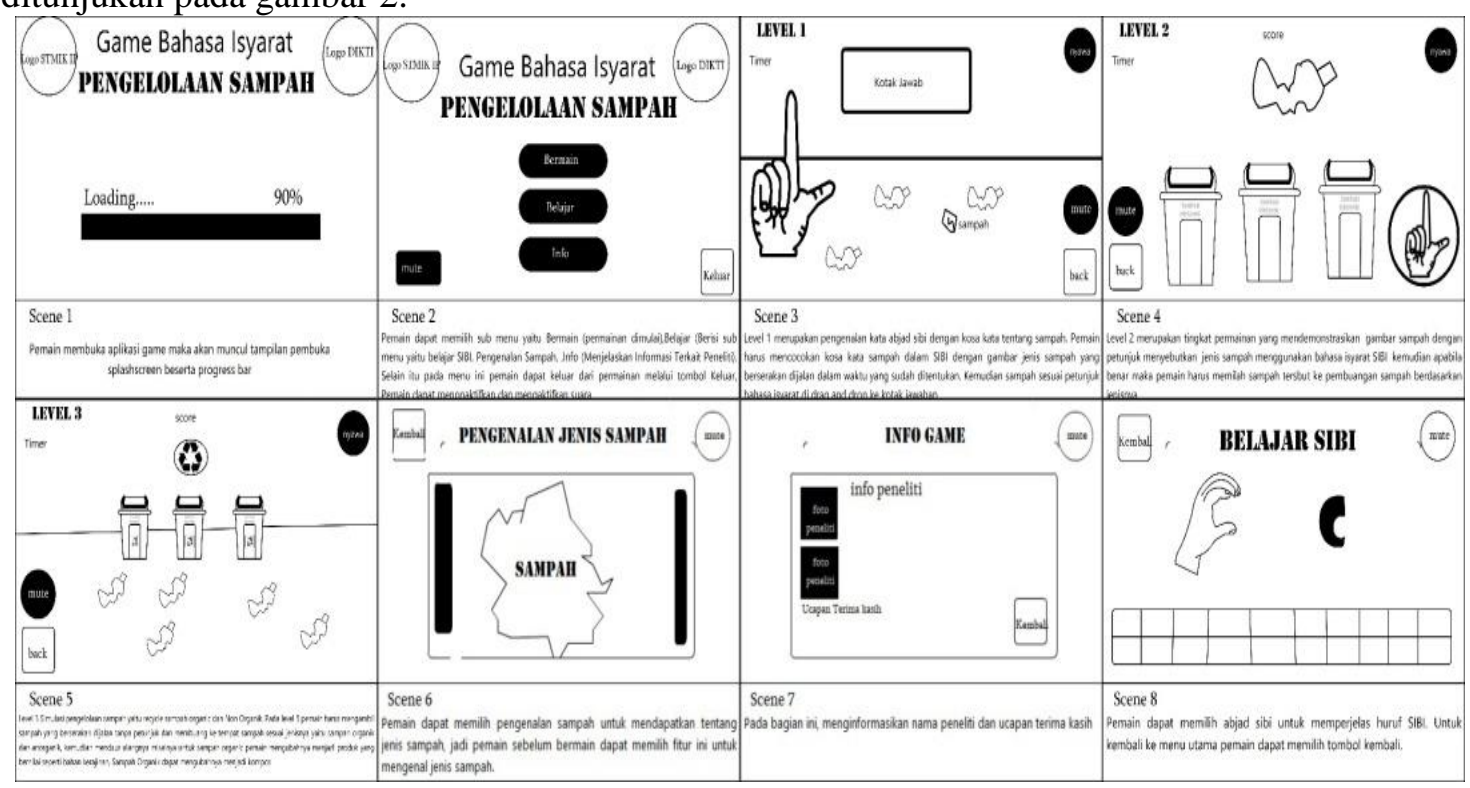

Gambar 2.Storyboard Game

Gambar 2 menunjukan alur scene dalam bentuk storyboard game yang sudah disesuaikan dengan storyline. Deskripsi dari storyline merupakan penjelasan untuk menggambarkan dalam bentuk sketsa storyboard karena melalui storyboard game akan diperoleh gambaran interface game yang dibangun. Untuk menjelaskan dialog antara pemain dengan game dapat dimodelkan dengan use case [15]. 


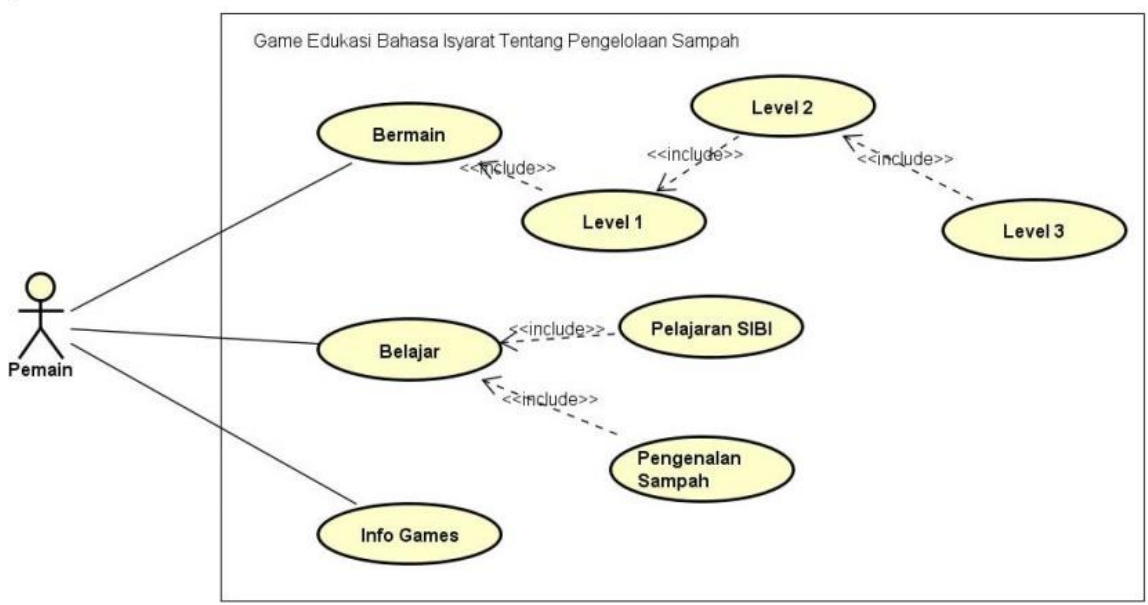

Gambar 3. Use case Game Edukasi

Gambar 3 merupakan interaksi pemain dengan sistem game. Pemain dapat memilih bermain maka game akan dimulai dengan level 1, untuk masuk ke level 2 maka misi level 1 harus diselesaikan terlebih dahulu, dan untuk masuk ke level 3 maka level 2 harus sudah tercapai. Apabila pemain memilih belajar maka game akan menampilkan dua pilihan yaitu belajar SIBI dengan menampilkan pembelajaran abjad SIBI dan pengenalan jenis sampah dengan menampilkan abjad SIBI. Pemain dapat memilih info game untuk menampikan informasi peneliti dan info cara bermain. Hasil dari aktivitas PreProduction selanjutnya didokumentasikan sebagai acuan atau landasan pengembangan game edukasi menggunakan Game Design Document, berikut adalah Ringkasan GDD untuk pengembangan Game Edukasi Bahasa isyarat Tentang Pengelolaan Sampah dapat tunjukan pada Tabel 2

Tabel 2. Cuplikan Game Design Dokumen

\begin{tabular}{|l|l|}
\hline \multicolumn{1}{|c|}{ Komponen } & \multicolumn{1}{|c|}{ Deskripsi } \\
\hline Game Overview & $\begin{array}{l}\text { Game Untuk Pembelajaran Bahasa Isyarat dengan menerapkan } \\
\text { pengetahuan Pengelolaan Sampah dalam rangka menumbuhkan sikap } \\
\text { peduli lingkungan. }\end{array}$ \\
\hline Genre & Game Edukasi \\
\hline Target Audience & Siswa /Siswi Tunarungu SLB \\
\hline Gameplay & $\begin{array}{l}\text { Aturan main pada game edukasi ini, pemain harus mengenal Bahasa } \\
\text { Isyarat Jenis Abjad SIBI sebagai petunjuk pada level permainan, apabila } \\
\text { belum memahaminya dapat memilih pembelajaran Bahasa Isyarat SIBI } \\
\text { terlebih dahulu, Interface game ditampilkan secara interaktif antara } \\
\text { pemainm dengan sistem game. }\end{array}$ \\
\hline Play Flow & $\begin{array}{l}\text { Mulai Bermain:Scene1 } \rightarrow \text { Scene } 2 \rightarrow \text { Scene3 } \rightarrow \text { Scene4 } \rightarrow \text { Scene5 } \\
\text { Pembelajaran SIBI:Scene1 } \rightarrow \text { Scene2 } \rightarrow \text { Scene8 }\end{array}$ \\
\hline Mission/Challenge & $\begin{array}{l}\text { Level terdiri tiga tingkatan yaitu level 1 Pengenalan Kata Abjad SIBI } \\
\text { dengan kosa kata pengenalan sampah. Level 2 Memilah sampah Organik } \\
\text { dan Non Organik sesuat petunjuk Bahasa Isyarat SIBI. Level 3 memilah } \\
\text { sampah dari jalan yang berserakan, dan dibuang berdasarkan jenisnya, } \\
\text { kemudian di recycle menjadi output produk yang bermanfaat }\end{array}$ \\
\hline
\end{tabular}

\subsection{Tahap Production}

Aktifitas pada tahapan ini adalah mengimplementasikan hasil storyboard dan use case diagram (UML) yang dideskripsikan pada GDD (Game Design Document) menjadi sebuah game. Melalui dokumen tersebut maka asset material apa saja yang dibutuhkan baik dalam bentuk grafis maupun audio, kemudian diintegrasikan menjadi kesatuan game berdasarkan storyboard yang sudah dirancang. Berikut adalah output dari tahapan production yang terdiri dari Splashscreen, Menu Utama Games, Level 1,Level 2, Level 3, Belajar SIBI, Pengenalan Sampah, dan Info Game. 


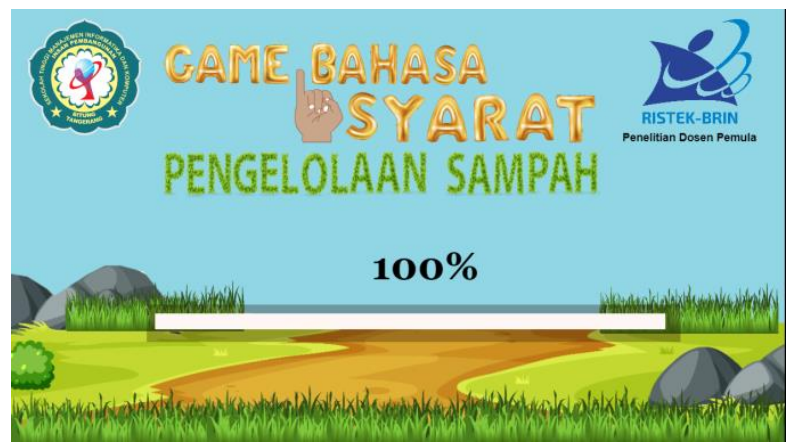

Gambar 4. SplashScreen

Pada gambar 4, setelah pemain membuka aplikasi game maka pertama kali muncul adalah SplashScreen yang menunjukan proses yang dimulai dari nol persen sampai seratus persen. Progressbar bergerak sesuai nilai persentase pada proses loading yang bertujuan untuk memunculkan menu utama game.

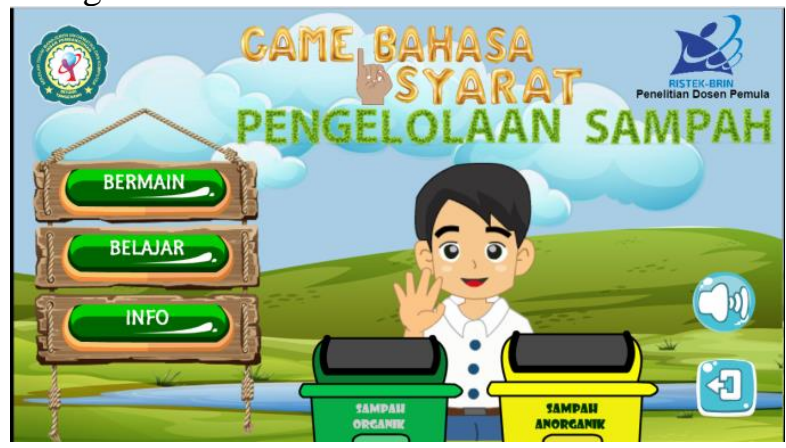

Gambar 5. Menu Utama Games

Setelah proses loading mencapai seratus persen maka game akan menampilkan menu utama yang ditunjukan pada gambar 5. Pada bagian menu utama, pemain dapat memilih bermain untuk memulai memainkan game, memilih belajar untuk masuk scene pembelajaran, dan memilih info untuk melihat informasi game seperti info peneliti dan cara bermain. Pemain dapat keluar dari permainan melalui tombol exit. Selain itu, music background game pada menu ini akan otomatis aktif, tetapi pemain dapat melakukan mute atau unmute melalui tombol mute.

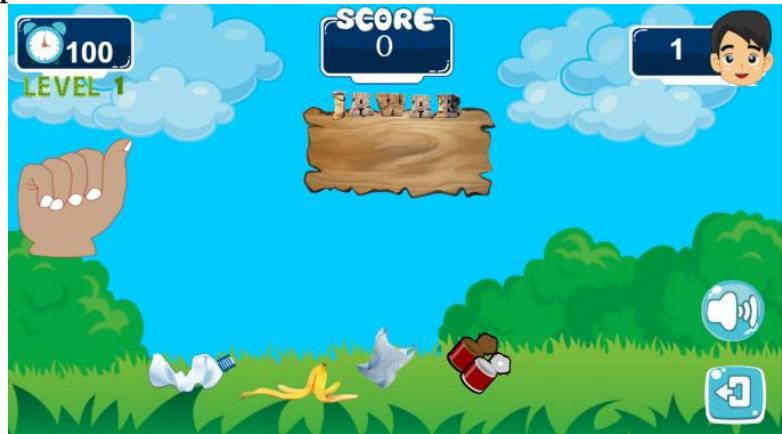

Gambar 6. Level 1

Berdasarkan gambar 6. Pemain berada pada level 1 yaitu Pengenalan Kata Abjad SIBI dengan kosa kata pengenalan jenis sampah. Aturan mainnya, pemain harus mengartikan maksud dari objek animasi abjad bahasa isyarat SIBI kemudian mengambil objek sampah ke kotak jawab menggunakan metode drag and drop. Drag and Drop pada objek sampah yaitu pemain melakukan menyeret objek sampah yang diinginkan kemudian menempatkan objek tersebut pada posisi yang dinginkan[16]. Misalnya soal yang keluar dari objek animasi abjad SIBI adalah kantong plastik maka pemain harus mencari salah satu kantong plastik yang berserakan untuk dimasukan ke kotak jawab. Apabila pemain salah memilih objek sampah maka nyawa berkurang satu. Pada level ini dibutuhkan pemahaman bahasa isyarat SIBI sebagai petunjuknya. Apabila pemain belum memahami bahasa isyarat SIBI pemain dapat keluar dari permainan 
kembali ke menu utama kemudian memilih belajar SIBI. Pemain dapat menonaktifkan music background dengan tombol mute.

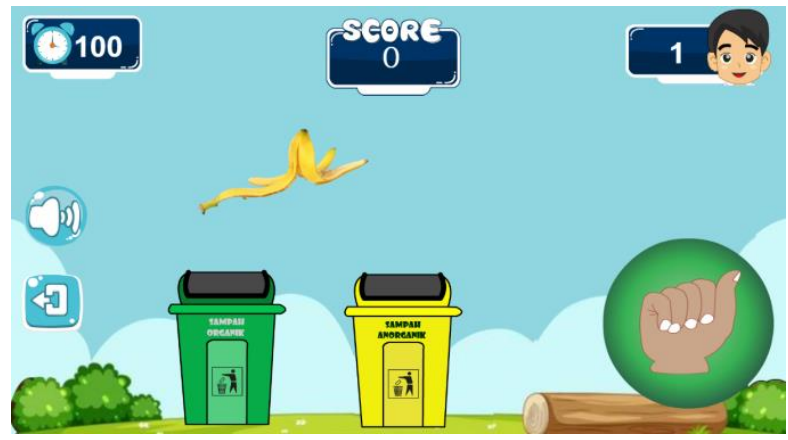

Gambar 7. Level 2

Gambar 7 menunjukan, pemain berada pada level 2. Syarat level 2 adalah pemain harus bisa menyelesaikan misi pada level 1 . Pada level 2, bentuk soal dalam mendemontrasikan objek sampah yang muncul secara random,kemudian pemain harus memilahnya berdasarkan jenis sampah organik atau anorganik, petunjuk dapat dilihat dari objek animasi abjad SIBI. Apabila salah memasukan jenis sampahnya maka nyawa berkurang satu. Jadi pada level ini pemahaman arti bahasa isyarat SIBI sangat dibutuhkan karena apabila salah memahami abjad SIBI akan berdampak pada kesalahan dalam memilah sampah yang tidak sesuai petunjuk penggunaan bahasa isyarat.

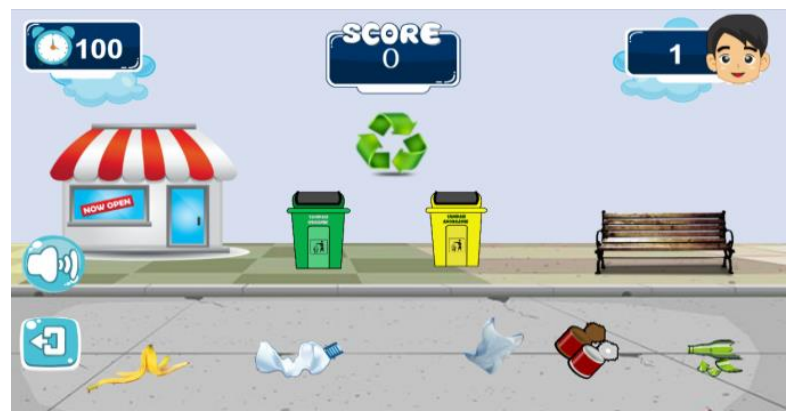

Gambar 8. Level 3

Level terakhir pada game edukasi ini adalah level 3 yang ditunjukan pada gambar 8. Pada level ini, pemain memilah sampah organik dan anorganik, apabila jumlah setiap jenis mencapai 10 maka dapat dilakukan recycle dan pemain dapat melakukan simulasi daur ulang menjadi produk yang bermanfaat. Misalnya sampah organik yang sudah dipilah mencapai 10 maka dapat direcycle menjadi pupuk kompos kemudian score akan bertambah 100 poin. Apabila pemain salah memilih objek sampah maka nyawa berkurang satu dan apabila timer habis maka game over. Pada level ini, pemain dapat menonaktifkan music background dengan tombol mute. Berdasarkan aturan permainan yang dibuat maka metode pembelajaran yang diterapkan pada Level 3 adalah menerapkan metode pembelajaran simulasi melalui proses yang dilakukan seolaolah dengan keadaan sebenarnya. Metode pembelajaran simulasi dapat membentuk keterampilan bertindak dalam kehidupan sehari-hari yang siap terjun dimasyarakat[17].

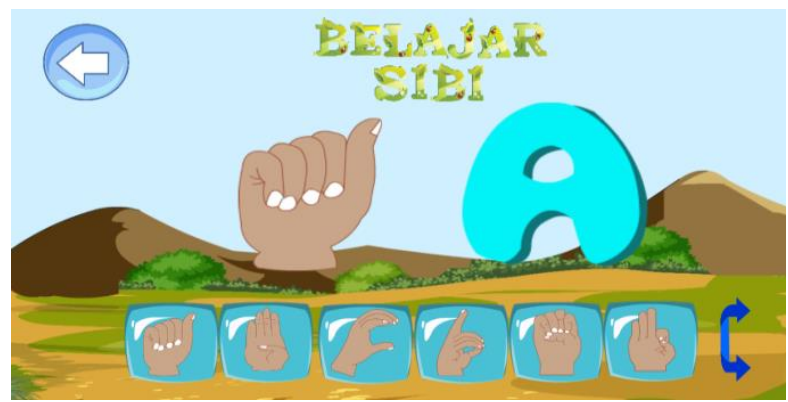

Gambar 9. Belajar SIBI 
Berdasarkan gambar 9, pemain dapat memilih belajar bahasa isyarat jenis SIBI, kemudian memilih abjad SIBI mulai dari huruf A sampai dengan Z. Setiap abjad bahasa isyarat SIBI akan muncul dengan memperagakan objek arti dalam bentuk abjad huruf. Pada fitur game ini merupakan fitur penunjang untuk belajar bahasa isyrat SIBI karena dalam game ini untuk menyelesaikan misi setiap level tidak hanya memahami pengetahuan sampah tetapi pemahaman bahasa isyrat dibutuhkan.

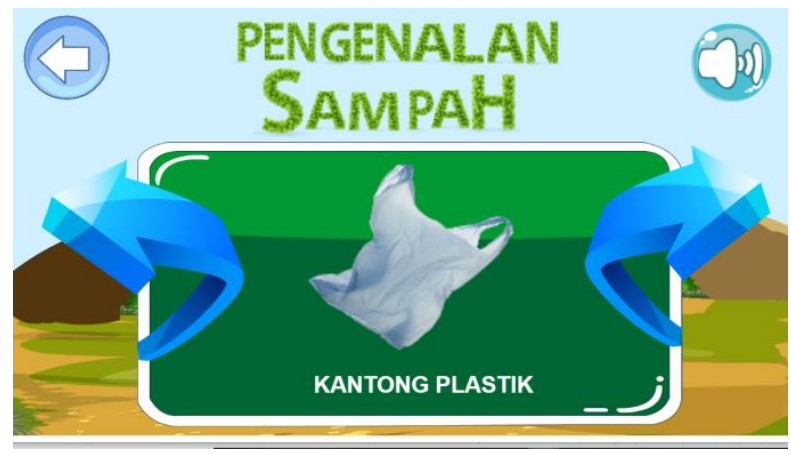

Gambar 10. Pengenalan Sampah

Gambar 10. Pemain dapat belajar tentang pengenalan sampah organik maupun anorganik melalui cara memperagakan objek sampah beserta penjelasannya. Apabila pemain memilih objek sampah maka akan muncul informasi jenis sampah dan informasi proses daur ulang sampah. Jadi pemain sebelum bermain dapat mempersiapkan terlebih dahulu pengetahhuan tentang sampah. Pemain dapat menonaktifkan audio melalui tombol mute. Selain itu pemain dapat kembali ke menu utama dengan memilih tombol kembali.

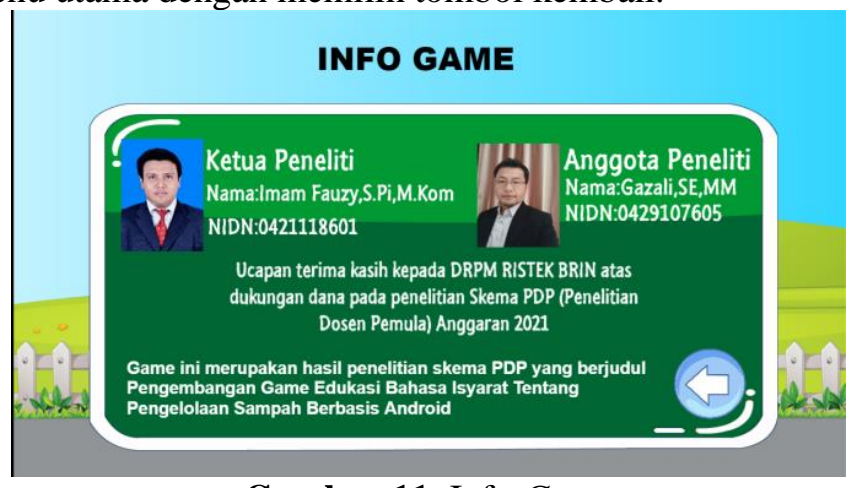

Gambar 11. Info Game

Gambar 11 merupakan informasi game yang berisi informasi peneliti dan cara bermain. Pemain dapat kembali ke menu utama dengan memilih tombol kembali.

\subsection{Tahap testing}

Tahapan pengujian game ini menggunakan metode blackbox testing yang berfokus pada input, proses dan output dan hasil pengujian yang sesuai. Hasil pengujian fungsi dilakukan pada perangkat mobile yang menjalankan sistem operasi Android yang berbasis open source. [18]. Berdasarkan hasil pengujian secara keseluruhan diperoleh kesimpulan valid. Berikut adalah hasil pengujian blackbox testing dapat ditunjukan pada tabel 3 .

Tabel 3. BlackBox Testing Game Edukasi

\begin{tabular}{lllllll}
\hline No & $\begin{array}{c}\text { Nama } \\
\text { Pengujian }\end{array}$ & Uji Input & $\begin{array}{c}\text { Kondisi } \\
\text { Sebelumya }\end{array}$ & $\begin{array}{c}\text { Hasil Yang } \\
\text { diharapkan }\end{array}$ & $\begin{array}{c}\text { Output } \\
\text { Pengujian }\end{array}$ & Status \\
\hline 1 & Loading & Memilih & Pemain & Proses loading & Proses loading & Valid \\
& Splashscreen & icon App & membuka & dilanjutkan & kemudian & \\
& & Game & game edukasi & menampilkan & dilanjutkan & \\
& Edukasi & bahasa isyarat & menu utama & menampilkan & \\
& & & tentang & games & menu utama & \\
& & & pengelolaan & & games & \\
& & & sampah & & & \\
\hline
\end{tabular}




\begin{tabular}{|c|c|c|c|c|c|c|}
\hline No & $\begin{array}{c}\text { Nama } \\
\text { Pengujian }\end{array}$ & Uji Input & $\begin{array}{c}\text { Kondisi } \\
\text { Sebelumya }\end{array}$ & $\begin{array}{l}\text { Hasil Yang } \\
\text { diharapkan }\end{array}$ & $\begin{array}{c}\text { Output } \\
\text { Pengujian }\end{array}$ & Status \\
\hline \multirow[t]{2}{*}{2} & \multirow[t]{2}{*}{$\begin{array}{l}\text { Kotak } \\
\text { Jawaban }\end{array}$} & $\begin{array}{l}\text { Jawaban } \\
\text { Salah }\end{array}$ & $\begin{array}{l}\text { Masuk ke } \\
\text { level } \\
\text { permainan }\end{array}$ & $\begin{array}{l}\text { Nyawa } \\
\text { Berkurang satu }\end{array}$ & $\begin{array}{l}\text { Nyawa } \\
\text { Berkurang } \\
\text { satu }\end{array}$ & Valid \\
\hline & & $\begin{array}{l}\text { Jawaban } \\
\text { Benar }\end{array}$ & $\begin{array}{l}\text { Masuk ke } \\
\text { level } \\
\text { permainan }\end{array}$ & $\begin{array}{l}\text { Score } \\
\text { Bertambah } 10 \\
\text { poin }\end{array}$ & $\begin{array}{l}\text { Score } \\
\text { Bertambah } 10 \\
\text { poin }\end{array}$ & Valid \\
\hline 4 & $\begin{array}{l}\text { Objek } \\
\text { Sampah }\end{array}$ & $\begin{array}{l}\text { Drag } \\
\text { Objek } \\
\text { Sampah } \\
\text { and Drop } \\
\text { Objek } \\
\text { sampah }\end{array}$ & $\begin{array}{l}\text { Objek sampah } \\
\text { muncul }\end{array}$ & $\begin{array}{l}\text { Objek Sampah } \\
\text { dapat di drag } \\
\text { sesuai } \\
\text { keingginan } \\
\text { pemaian dan di } \\
\text { drop ke kotak } \\
\text { Jawaban }\end{array}$ & $\begin{array}{l}\text { Objek Sampah } \\
\text { dapat di drag } \\
\text { sesuai } \\
\text { keingginan } \\
\text { pemaian dan } \\
\text { di drop ke } \\
\text { kotak Jawaban }\end{array}$ & Valid \\
\hline \multirow[t]{2}{*}{5} & \multirow[t]{2}{*}{$\begin{array}{l}\text { Tombol } \\
\text { Recycle } \\
\text { Sampah }\end{array}$} & $\begin{array}{l}\text { Sampah } \\
\text { organik } \\
>10\end{array}$ & $\begin{array}{l}\text { Pemain } \\
\text { berada di level } \\
3\end{array}$ & $\begin{array}{l}\text { Tombol recycle } \\
\text { sampah aktif } \\
\text { dan proses } \\
\text { recycle sampah } \\
\text { organik dapat } \\
\text { dilakukan }\end{array}$ & $\begin{array}{l}\text { Tombol } \\
\text { recycle } \\
\text { sampah aktif } \\
\text { dan proses } \\
\text { recycle } \\
\text { sampah } \\
\text { organik dapat } \\
\text { dilakukan }\end{array}$ & Valid \\
\hline & & $\begin{array}{l}\text { Sampah } \\
\text { an } \\
\text { organik } \\
>10\end{array}$ & $\begin{array}{l}\text { Pemain } \\
\text { berada di level } \\
3\end{array}$ & $\begin{array}{l}\text { Tombol recycle } \\
\text { sampah aktif } \\
\text { dan proses } \\
\text { recycle sampah } \\
\text { Anorganik } \\
\text { dapat } \\
\text { dilakukan }\end{array}$ & $\begin{array}{l}\text { Tombol } \\
\text { recycle } \\
\text { sampah aktif } \\
\text { dan proses } \\
\text { recycle } \\
\text { sampah } \\
\text { AnOrganik } \\
\text { dapat } \\
\text { dilakukan }\end{array}$ & Valid \\
\hline \multirow[t]{2}{*}{6} & \multirow[t]{2}{*}{ Timer } & Timer $>0$ & $\begin{array}{l}\text { Pemain } \\
\text { berada di level } \\
\text { permain }\end{array}$ & $\begin{array}{l}\text { Nilai timer } \\
\text { berkurang } 1 \\
\text { poin }\end{array}$ & $\begin{array}{l}\text { Nilai timer } \\
\text { berkurang } 1 \\
\text { poin }\end{array}$ & Valid \\
\hline & & Timer $=0$ & $\begin{array}{l}\text { Pemain } \\
\text { berada di level } \\
\text { permain }\end{array}$ & $\begin{array}{l}\text { Nilai timer } \\
\text { berhenti di } 0 \\
\text { dan permainan } \\
\text { selesai }\end{array}$ & $\begin{array}{l}\text { Nilai timer } \\
\text { berhenti di } 0 \\
\text { dan permainan } \\
\text { selesai }\end{array}$ & Valid \\
\hline
\end{tabular}

\subsection{Tahapan Beta}

Tahapan ini dilakukan untuk mendapatkan feedback tentang kualitas pengalaman game edukasi dari pengguna yaitu dilakukan oleh 20 responden siswa/siswi tunarungu di SLB Negeri Banjar melalui pendampingan khusus oleh guru bahasa isyarat. Aspek yang diuji didasarkan pada kriteria Nielsen. Berikut adalah hasil perhitungan usability testing berdasarkan skala likert dapat ditunjukan pada tabel 4 .

Tabel 4. Usability Model Nielsen

\begin{tabular}{clll}
\hline \multirow{2}{*}{ Aspek } & \multicolumn{1}{c}{ Pertanyaan Responden } & $\%$ & $\begin{array}{c}\text { \% per } \\
\text { Aspek }\end{array}$ \\
\hline \multirow{3}{*}{ Learnability } & $\begin{array}{l}\text { Apakah tampilan game pertama dibuka mudah } \\
\text { dikenali? }\end{array}$ & $84 \%$ & \\
\cline { 2 - 2 } & Apakah Game mudah diinstal? & $80 \%$ \\
\cline { 2 - 2 } & Apakah tidak ada kesulitan dalam memulai game? & $77 \%$ & \\
\cline { 2 - 2 } & &
\end{tabular}




\begin{tabular}{|c|c|c|c|}
\hline & Apakah fitur yang tersedia mudah dipelajari? & $78 \%$ & \multirow{3}{*}{$73 \%$} \\
\hline \multirow{2}{*}{ Efficiency } & Apakah fitur dapat ditampilkan dengan cepat? & $75 \%$ & \\
\hline & Apakah respon Jawaban ditampilkan cepat? & $71 \%$ & \\
\hline \multirow{3}{*}{ Memorability } & Apakah judul game mudah diingat & $73 \%$ & \multirow{3}{*}{$73.33 \%$} \\
\hline & Apakah nama fitur mudah diingat & $75 \%$ & \\
\hline & Apakah cara bermain mudah diingat & $72 \%$ & \\
\hline \multirow{2}{*}{ Error } & Apakah fitur berfungsi dengan baik & $79 \%$ & \multirow{2}{*}{$79 \%$} \\
\hline & Bagaimana kelancaran proses instalasi & $79 \%$ & \\
\hline \multirow{4}{*}{ Satisfaction } & $\begin{array}{l}\text { Apakah mendapatkan pemahaman dari game } \\
\text { edukasi }\end{array}$ & $85 \%$ & \multirow{3}{*}{$82.67 \%$} \\
\hline & Apakah permainan yang disajikan menarik & $79 \%$ & \\
\hline & $\begin{array}{l}\text { Apakah ada keinginan untuk bermain game eduaksi } \\
\text { lagi? }\end{array}$ & $84 \%$ & \\
\hline & Rata-Rata & & $77 \%$ \\
\hline
\end{tabular}

Berdasarkan tabel 6 pengujian usability testing aspek nielsen diperoleh nilai Learnability $80 \%$ dikategorikan baik, Efficiency sebesar $73 \%$ dikategorikan baik, Memorability sebesar 73.33\%\% dikategorikan baik, Error sebesar 79\% dikategorikan baik dan Satisfaction sebesar $82,67 \%$ dikategorikan sangat baik. Secara keseluruhan rata-rata sebesar 77\% maka berdasarkan skala likert dikategorikan baik. Jadi secara keseluruhan game edukasi yang dibangun baik untuk digunakan oleh siswa/siswi tunarungu SLB.

\subsection{Analisis Perbandingan Hasil Penelitian Terdahulu}

Penelitian terdahulu dengan judul "Edukasi Game Jaga Sungai Kapuas Berbasis Android Menggunakan Construct 2" menghasilkan game edukasi dengan gameplay pemain harus menggerakan Perahu disungai Kapuas ke segala arah untuk mengumpulkan sampah. Hasil pengujian berdasarkan aspek Efficiency $85 \%$ Functionality $93 \%$, Usability $88 \%$ dan Portability $89 \%$ dari 20 responden pengguna awam sebesar $89.44 \%$ dinyatakan sangat layak untuk digunakan[5].

Penelitian yang berjudul "Pembuatan Game Online BoMCleaN sebagai Media Pembelajaran Kebersihan Lingkungan" menggunakan siklus pengembangan perangkat lunak $(S D L C)$ menghasilkan game edukasi dengan gameplay pemain akan memainkan sebuah karakter platform slide dengan teknik mengambil sampah organik dan anorganik yang terjatuh dengan fitur multiplayer. Pengujian untuk menentukan kepuasan berdasarkan responden wanita karir, ibu rumah tangga, dan mahasiswa dengan kriteria dihasilkan bahwa game sudah sangat baik 7\%, Game kurang menantang 20\%, Desain Game kurang menarik 13\%, Game mengalami bug $60 \%$ dengan saran harus dilakukan perbaikan bug[6].

Penelitian berjudul "Perancangan dan Implementasi Game Edukasi Pengolahan Sampah Organik dan Anorganik Berbasis Android Pada Kelas VII SMP Fajar Sentosa " metode pengembangan mengunakan SDLC menghasilkan game edukasi yang digunkan untuk siswa SMP Fajar Sentosa Kelas VII dengan gameplay pemain memindahkan sampah ke mesin yang sesuai kemudian mengembalikannya apabila tahapan pengolahan belum selesai, apabila mencapai tahap akhir dapat dipindahkan ke truk. Pengujian berdasarkan 20 siswa yang disurvei dari kelas VII SMA Fajar Sentosa menggunakan skala Guttman menghasilkan skala koefisien reproduktifitas > 0,9 dan koefisien skalabilitas > 0,6 yang berarti sistem permainan dan informasi permainan dianggap layak[7].

Perbedaan dari hasil penelitian ini adalah menggunakan metode siklus pengembangan game (GDLC) dan menghasilkan game edukasi yang digunakan siswa/siswi tunarungu SLB pada pembelajaran bahasa isyarat dengan gameplay terdiri dari tiga tingkatan kesulitan dengan menerapkan bahasa isyarat jenis SIBI pada setiap levelnya yaitu Level1 mengenal jenis sampah, Level2 Memilah sampah, dan Level3 recycle sampah organik dan anorganik. Pengujian usability nielsen dilakukan oleh 20 responden siswa/siswi tunarungu SLB menghasilkan nilai Learnability $80 \%$, Efficiency 73\%, Memorability 73.33\%\%, Error 79\%, Satisfaction 82,67\% 
dengan keseluruhan nilai 77\% maka berdasarkan skala likert maka game edukasi yang dibangun baik untuk digunakan oleh siswa/siswi tunarungu SLB.

\section{Kesimpulan}

Hasil dari penelitian dapat disimpulkan bahwa pendekatan GDLC(Game Development Life Cycle) sesuai untuk membuat game edukasi. Hasil dari pengembangan game ini adalah SplashScreen, menu utama, tiga tingkat kesulitan dalam bahasa isyarat SIBI yaitu, level 1 pengenalan jenis sampah, level 2 klasifikasi sampah organik, level 3 daur ulang sampah organik dan anorganik, pembelajaran pengenalan sampah, pembelajaran SIBI dan Info Permainan. Metode pembelajaran yang dihasilkan melalui pengembangan game ini adalah metode memperagakan objek yang terdapat pada pengenalan sampah, belajar SIBI,dan metode pembelajaran simulasi yang terdapat pada level 3 simulasi recycle sampah. Hasil Pengujian fungsional secara keseluruhan valid. Pengujian Usability berdasarkan aspek Learnability, Efficiency,Memorability, dan Error dikategorikan baik, sedangkan aspek Satisfaction dikategorikan sangat baik, secara keseluruhan rata-rata pengujian usability model Nielsen adalah $77 \%$ sehingga game edukasi yang dihasilkan dikategorikan baik untuk digunakan oleh siswa/siswi tunarungu SLB.

\section{Ucapan Terima Kasih}

Terima kasih atas kesempatan dan dukungan dana dari Direktorat Riset dan Pengabdian kepada Masyarakat (DRPM) RISTEK BRIN pada skema Penelitian Dosen Pemula untuk Tahun Anggaran 2021 Berdasarkan No Kontrak 065 /SP2H/LT/DRPM/2021; 041/SP2H/RDPKRMONO/LL4/2021;444/K-1/STMIK IP/VI/2021.

\section{Daftar Pustaka}

[1] Badan Pusat Statistik, "Statistik Lingkungan Hidup Indonesia (SLHI) 2018," Badan Pus. Stat. Indones., pp. 1-43, 2018, doi: 3305001.

[2] Y. F. Narut and M. Nardi, "Analisis Sikap Peduli Lingkungan Pada Siswa Kelas VI Sekolah Dasar di Kota Ruteng," Sch. J. Pendidikan. dan Kebudayaan., vol. 9, no. 3, pp. 259-266, 2019, doi: 10.24246/j.js.2019.v9.i3.p259-266.

[3] A. S. Nugraheni, A. P. Husain, and H. Unayah, "Optimalisasi Penggunaan Bahasa Isyarat Dengan Sibi Dan Bisindo Pada Mahasiswa Difabel Tunarungu Di Prodi Pgmi Uin Sunan ...," J. Holistika, 2021, [Online]. Available: https://jurnal.umj.ac.id/index.php/holistika/article/view/9355.

[4] D. W. P. A. P. N. Erri Wahyu Puspitarini, "Game Edukasi Berbasis Android Sebagai Media Pembelajaran Untuk Anak Usia Dini," J I M P - J. Inform. Merdeka Pasuruan, vol. 1, no. 1, 2016, doi: 10.37438/jimp.v1i1.7.

[5] N. A. F. Ichida, H. Nasution, and A. Perwitasari, "Edukasi Game Jaga Sungai Kapuas Berbasis Android Menggunakan Construct 2," J. Sist. dan Teknol. Inf., vol. 6, no. 3, p. 124, 2018, doi: 10.26418/justin.v6i3.26806.

[6] K. M. Shihab, S. Sussi, R. Munadi, R. R. Prasojoe, and N. Fitriyanti, "Pembuatan Game Online BoMCleaN sebagai Media Pembelajaran Kebersihan Lingkungan," J. Edukasi dan Penelit. Inform., vol. 5, no. 1, p. 113, 2019, doi: 10.26418/jp.v5i1.29874.

[7] M. R. Prinanto and S. Suwarni, "Perancangan Dan Implementasi Game Edukasi Pengolahan Sampah Organik Dan Anorganik Berbasis Android Pada Kelas Vii Smp Fajar Sentosa," J. Teknol. Inf., vol. 3, no. 1, p. 4, 2017.

[8] S. N. Wahyuni and C. Andiyoko, "Pembuatan Game Berbasis Pembelajaran Menggunakan Rpg Maker Mv," J. Comput. Networks, Archit. High Perform. Comput., vol. 1, no. 1, pp. 24-28, 2018, doi: 10.47709/cnapc.v1i1.5.

[9] J. L. Putra and C. Kesuma, "Penerapan Game Development Life Cycle Untuk Video Game Dengan Model Role Playing Game," vol. 1, no. 1, pp. 27-34, 2021.

[10] S. L. Rahayu and F. Fujiati, "Penerapan Game Design Document dalam Perancangan Game Edukasi yang Interaktif untuk Menarik Minat Siswa dalam Belajar Bahasa 
Inggris," J. Teknol. Inf. dan Ilmu Komput., vol. 5, no. 3, p. 341, 2018, doi: 10.25126/jtiik.201853694.

[11] I. F. M. Rachmat, "Implementasi Metode Rational Unified Process Pada Perancangan Aplikasi Pembagian Harta Warisan Berbasis Android," IPSIKOM, vol. 5, no. 2, pp. 110, 2017.

[12] F. Adnan, B. Prasetyo, and N. Nuriman, "Usability testing analysis on the Bana game as education game design references on junior high school," J. Pendidik. IPA Indones., vol. 6, no. 1, pp. 88-94, 2017, doi: 10.15294/jpii.v6i1.9597.

[13] W. Warjiyono and C. M. Hellyana, "Pengukuran Kualitas Website Pemerintah Desa Jagalempeni Menggunakan Metode Webqual 4.0," J. Teknol. Inf. dan Ilmu Komput., vol. 5, no. 2, p. 139, 2018, doi: 10.25126/jtiik.201852666.

[14] I. F. M. Rachmat and G. Gazali, "Development of an Android-Based Sign Language Education Game Using a Scrum-Game Approach," JUITA J. Inform., vol. 9, no. 1, p. 57, 2021, doi: 10.30595/juita.v9i1.8721.

[15] Munawar, Analisis Perancangan Sistem Berorientasi Objek dengan UML. Bandung, 2018.

[16] A. R. Farizki, H. N. Palit, and A. Setiawan, "Aplikasi Pembelajaran Rangkaian Listrik Sederhana Berbasis Android," J. Infra, vol. 4, no. 1, pp. 41-47, 2016.

[17] T. Handayani, "Penerapan Metode Simulasi Pada Materi Pembelajaran Press Conference Guna Meningkatkan Soft Skill Dan Mutu Pembelajaran Di Smkn 3 Bandung Tingkat 11 (Ap4)," J. Penelit. Pendidik., vol. 17, no. 2, 2017, doi: 10.17509/jpp.v17i2.8243.

[18] E. Erlinda and M. Masriadi, "Perancangan Aplikasi Mobile Kamus Istilah Komputer Untuk Mahasiswa Baru Bidang Ilmu Komputer Berbasis Android," J. Teknologi. Dan Open Source, vol. 3, no. 1, pp. 30-43, 2020, doi: 10.36378/jtos.v3i1.551.

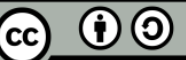

